\title{
A study on the Relationship Between Employee Satisfaction and Employees' Performance
}

\author{
Ashish Ranga ${ }^{1}$ and Reshma Kamboj ${ }^{2}$ \\ 1,2 B.C.I.H.M.C.T, New Delhi \\ 1ashish@bcibmct.ac.in
}

\begin{abstract}
A performance appraisal (PA), to boot ascertained as a performance review, performance analysis, (career) development discussion, or employee appraisal is also a way by that the work performance of an associate employee is documented and evaluated. The Performance appraisal has been viewed by lecturers and human resource practitioners as a significant human resource management practices as a result of it yields selections that area unit crucial and integral to varied human resource actions and outcomes. Yet, an honest Performance appraisal system remains a smart challenge for managers and employees thanks to psychological feature, psychological feature and behavioral factors associated with it. Employee outcomes among the sort of labor performance, effective structure commitment and turnover intention area unit is undeniably variety of the foremost necessary issues during a corporation. The management has to be compelled to concentrate to the extent of satisfaction in performance appraisal to substantiate that employees are happy and contribute utterly to their organization throughout the tenure of their employment with the organization. This can be often very crucial to support the expansion of an organization. The aim of this paper is to specialize in the impact of performance appraisal on employee's performance and to boot trace impact of motivation issue, as a result of it affects the association of performance appraisal and employee's performance.

The paper reviews the

- The relationship between perceptions of performance appraisal fairness and employee engagement in the context of the business organization.

- The reaction of employees to these performance assessments.
\end{abstract}

Keywords: Performance Appraisal, Work Performance, worker Satisfaction 


\section{A. Introduction}

Performance appraisal has a distinct purpose in management procedures since from the time of Warfare II. It's one in each of the oldest disciplines. People do opt for others more as people opt for themselves with every passing day, business organization face aggressive competition attributable to globalization; therefore, they need plenty of competencies to satisfy these challenges. Performance management is important to the house of human resource practices and Performance appraisal can be a decisive a vicinity of performance management. Performance management can be a system in essence used by prime management like executives, managers and supervisors therefore on align employee performance with the firm's goal.

Performance management is used for dissimilar functions like; to stipulate measures of performance, monitor the employee performance, and to provide employees with feedback regarding their performance. Performance appraisal is used to stipulate the extent to it associate employee performs his/her work effectively. plenty of comprehensive definition is that Performance appraisal can be a proper, structured system of meaning associated evaluating associate employee's job connected behaviors and outcome to induce but and why the employee is presently working on the task and he the employee can perform plenty of effectively among the long term, therefore, the employee, organization and society and each one profit.

\section{B. Literature Review}

Performance appraisal is also outlined as a structured formal interaction between a subordinate and supervisor, that typically takes the shape of a periodic interview (annual or semiannual), throughout which the work performance of the subordinate is examined and mentioned, with a read to characteristic weakness and strengths further as opportunities for improvement and skills development. In many organization - but not all - appraisal results square measure used, either directly or indirectly, to help verify reward outcome. That is, the appraisal results square measure accustomed to confirm the upper activity employees to induce the majority of accessible earnings can increase bonuses, and promotions. By constant token, appraisal results square measure accustomed to confirm the poorer performers may want some sort of counsel, or among the acute cases, amendment dismissal or decreases in pay. This can be associated with acceptable use of performance appraisal - the assignment and justification of rewards and penalties - very unsure and contentious matter. Thus, Performance appraisal is deemed as decisively imperative human resource perform as a result of performance appraisal results square measure used for group action deciding and for the type of completely different functions yentas body selections, employee development and personnel analysis.

According to (Rogers and Hunter 1991) stated that goal setting is the fundamental aspect for an organization. They also indicated that productivity 
gains will correlate with the extent of top management support for and employees' participation in the process of setting objectives. It is, therefore, a motivational process which also gives the individual the feeling of being involved and creates a sense of ownership for employees. According to Fathom, Ningrum, and Abas (2018), the performance of an employee will be good, if employees have high expertise, willingness to work, the rewards/wages are feasible and have hope for the future. Optimal performance will be realized when the organization can select employees who have the motivation and skills appropriate to their work and choose conditions that enable them to work optimally. The planning phase consists of the agreement on a formal development plan for the employees. Actually, this plan should be based on requisite skills, behaviors and knowledge and key competencies that will be required to achieve the objectives and targets set.

The findings of (Nyembezi, 2009) development plan can also include long-term development initiatives which are usually based on potential and good performance. According to (Schneier et al., 1987) Planning is a continuous process in performance management and should be executed with great care. Also, the study of Armstrong and Baron (2004) pointed out that at its best; performance management is a tool to ensure that managers manage effectively. Therefore, performance management system should ensure the management of employees or teams know how and understand what is expected from them, and have the skills and ability to deliver on the expectations and be supported by the organization to develop the capacity to meet these expectations are given feedback on their performance; and have the opportunity to discuss and contribute to individual and team aims and objectives. Objectives or goals describe some targets to be accomplished by individuals, departments and organizations over a period of time. They can be expressed as targets to be met, for example, sales, and tasks to be completed before the deadline.

According to (Marion, 1998) It is important for managers to develop a fully integrated strategy which enables the different forms of communication to contribute to the success of the firm's mission or common goal. Moreover, (Welch \& Jackson, 2007) finds that continuous communication or exchanging information between an organization's strategic managers and its internal stakeholders should be designed to promote commitment to the organization \& known to its changing environment.

According to (Cunneen, 2006), stressed that coaching comes naturally, and could take place during the review meetings or should be carried out throughout the year. Also, in this phase, training may be required to improve their skills. Teke (2002) suggested that linking training to identified performance gaps, training will be focused, specific and relevant.

According to (Huang \& Hu, 2007) In most organizations, they will not have only one corporate scorecard for the company as a whole, but will also have separate scorecards for each division/employee that feeds into the overall 
scorecard the first process is translating the vision which helps managers build a consensus around the organization's vision and strategy According to (Kaplan \& Norton, 1996) the customer perspective measures include client satisfaction, client profitability or time, price and quality.

According to the suggestion of (Locke 2004), the pay-for-performance principle involves providing monetary rewards through carefully designed compensation system that base pay on measured performance within the control participants. According to (Delery \& Doty 1996), employee performance appraisal is defined as 'the process of identifying, evaluating and developing the work performance of the employee in the organization, so that organizational goals and objectives are effectively attained while simultaneously benefiting employees in terms of recognition, receiving feedback, and offering career guidance'. Appraisals can be based on results or behavior. Behavior-based appraisals focus on the behaviors of individuals necessary to perform the job effectively, whereas results-oriented appraisals focus merely on the consequences of those behaviors.

\section{Objectives of the study}

This study is devoted to spotting the relationship between employee satisfaction and performance appraisal. We examine however performance appraisals have an effect on the employee's future performance.

The paper finds the:

- The relationship between perceptions of performance appraisal fairness and employee engagement in the context of the business organization.

- The reaction of employees to these performance assessments.

\section{Research methodology}

Information was collected from 123 staff from several organizations relating many tiny and massive welcome industries, throughout Delhi/NCR. Findings - Results from a survey of 123 staff showed that the link between performance appraisal satisfaction and worker outcomes within the form of labor performance, emotional structure commitment and turnover intent was mediate by employees' intrinsic motivation.

This study provides two hypotheses. One is to explore performance appraisal practices and to understand its relationship with particular demographic characteristics of the hotel.

H1: There is a set of performance appraisal practices which are used in 2 stars and 3-star hotels in Delhi NCR.

H2: There is a positive relationship between the promotion policies and demographic characteristics of hotels. 


\section{E. Research limitations}

The 3 most vital limitations are the sample used, that is principally from the Delhi/NCR, the measure employed in the study and therefore the reliance on self-reported form information. Consequently, experimental studies are required to scrutinize relation problems. Analysis Findings during this section, the results of the empirical study are according.

\section{F. Research Findings}

In this section, the results of the empirical study are reported. Results are presented in respect of the relationship between satisfaction with performance appraisal and employee outcomes, in the form of work performance, affective organizational commitment and turnover intention, within the Indian context.

Table 1. Distribution Of Sample According To Demographic Characteristics $(\mathrm{N}=123)$

\begin{tabular}{lll}
\hline & Number & Percentage \\
\hline Type Of Hotel & \multicolumn{2}{c}{} \\
Independent Hotel & 64 & 48 \\
Non Chain Hotel & & 52 \\
\hline Category Of Hotel & 65 & 52.8 \\
$3 *$ & 58 & 47.2 \\
$2^{*}$ & & \\
\hline Age Of Hotel & 44 & 35.8 \\
$\leq 5$ & 58 & 47.2 \\
$6-10$ & 5 & 4.1 \\
$11-15$ & 16 & 13 \\
$\geq 15$ & & \\
\hline Number Of Employees In Hotel & 70 & 56.9 \\
$\leq 50$ & 44 & 35.8 \\
$51-100$ & 9 & 7.3 \\
$\geq 100$ & & \\
\hline Age & 40 & 32.5 \\
$20-25$ & 45 & 36.6 \\
$26-30$ & 27 & 22 \\
$31-35$ & 11 & 8.9 \\
$\geq 35$ & & 86.2 \\
\hline Gender & 106 & 13.8 \\
Male & 17 & 48.8 \\
Female & & 51.2 \\
\hline Marital Status & 60 & \\
Unmarried & 63 & \\
Married & & \\
\hline
\end{tabular}




\begin{tabular}{lll}
\hline & Number & Percentage \\
\hline Education & 91 & 74 \\
10+2 Or Less & 18 & 14.6 \\
Graduate & 14 & 11.4 \\
Post Graduate & & \\
\hline Job Position & 51 & 4105 \\
Operationals & 53 & 43.1 \\
Supervisory & 19 & 15.4 \\
Managerial & & \\
\hline Monthly Income & 40 & 32.5 \\
Below 15.000 & 62 & 50.4 \\
15.001-25.000 & 21 & 17.1 \\
25.001-35.000 & & \\
Above 35.000 & & \\
\hline How Many Years You Have Been & & 66.7 \\
Working In This Hotel & 82 & 18.7 \\
Below 3 Years & 23 & 10.6 \\
4-6 & 13 & 2.4 \\
7-10 & 3 & 1.6 \\
11-15 & 2 & 42.3 \\
Above 15 & & 20.3 \\
Would You Like To Continue Your & & 37.4 \\
Yervice With The Same Hotel & 52 & \\
No & 25 & \\
Uncertain & 46 & \\
\hline & & \\
\hline & &
\end{tabular}

Table 1 presents the distribution of sample hotel organizations with respect to the demographics used in the study. In term of hotel organization, 59 $(48 \%)$ are independent hotels $64(52 \%)$ are non-chain hotel. In term of hotel category $65(52.8 \%)$ are 3 star $58(47.2 \%)$ are 2 star hotels. In terms of age of the property, $44(35.8 \%)$ hotels existed for less than 5 years, $58(47.2 \%)$ existed for 6 to 10 years, $5(4.1 \%)$ existed for 11 to 15 years, $16(13 \%)$ existed for above 15years.In terms of number of Staff, there are $70(56.9 \%)$ hotels have less than 50 employees, $44(35.8 \%)$ have 51 to 100 employees, $9(7.3 \%)$ have more than 100 employees.

In term of the age of employees, $40(32.5 \%)$ are $20-25$ years of age, 45 $(36.6 \%)$ are $26-30$ years of age, $27(22.0 \%)$ are $31-35$ years of age and $11(8.9 \%)$ are above 35 years of age. In term of gender $106(86.2 \%)$ male and $17(13.8 \%)$ female was contacted. Of these, $60(48.8 \%)$ were unmarried whereas $63(51.2 \%$ were married. In terms of education, 91 respondents $(74 \%)$ were either educated till higher secondary or less, 18 (14.6\%) were graduates and only 14 $(11.4 \%)$ were postgraduates. With regards to respondents' monthly income, 40 $(32.5 \%)$ earned less than INR 15.000, 62 (50.4\%) earned between INR 15.001 
to INR 25.000, $21(17.1 \%)$ earned between INR 25.001 to INR 35.000. No respondent earned more than INR 35.000.

In terms of job position $51(41.05 \%)$ respondents work at the operational level, 53 (43.1\%) work at the supervisory level, and $19(15.4 \%)$ work at managerial level. In terms of working in the current hotel, $82(66.7 \%)$ have been working for less than 3 years, $23(18.7 \%)$ have been working for 4-6 years, $13(10.6 \%)$ have been working for 7-10 years, $3(2.4 \%)$ have been working for 11-15 years, and $2(1.6 \%)$ have been working for more than 15 years. When asked about the intention to continue service with the same hotel, $52(42.3 \%)$ were willing, $25(20.3 \%)$ were unwilling and $46(37.4 \%)$ were uncertain.

Table 2 Descriptive Statistics

\begin{tabular}{|c|c|c|c|}
\hline & Mean & $\begin{array}{l}\text { Std. } \\
\text { Deviation }\end{array}$ & Analysis N \\
\hline $\begin{array}{l}\text { Are you aware of Performance appraisal system } \\
\text { in your organization }\end{array}$ & 2.6341 & .82251 & 123 \\
\hline $\begin{array}{l}\text { The hotel has fair promotion opportunities } \\
\text { for every employee }\end{array}$ & 2.8374 & 1.01927 & 123 \\
\hline $\begin{array}{l}\text { Promotion is totally based on employee } \\
\text { performance }\end{array}$ & 2.9350 & .96445 & 123 \\
\hline My job is helping me in my career & 2.8130 & .93519 & 123 \\
\hline My superior provides me equal opportunities & 2.5610 & 1.09504 & 123 \\
\hline Working with this hotel is enjoyable & 2.7480 & .98008 & 123 \\
\hline $\begin{array}{l}\text { The good result of performance appraisal will } \\
\text { lead to promotion }\end{array}$ & 2.6423 & 1.01731 & 123 \\
\hline Do you love to accept challenges related to your & & & \\
\hline Job & 2.8618 & 1.15464 & 123 \\
\hline Are you aware of the goals of your hotel & 3.2764 & .72768 & 123 \\
\hline $\begin{array}{l}\text { Do you have a favorable work culture and } \\
\text { environment }\end{array}$ & 2.8130 & 1.18978 & 123 \\
\hline $\begin{array}{l}\text { Does your manager communicate the right } \\
\text { information to you about your appraisal }\end{array}$ & 2.7480 & 1.19832 & 123 \\
\hline $\begin{array}{l}\text { Does your superior delegate authorities to } \\
\text { employees }\end{array}$ & 2.7480 & 1.13509 & 123 \\
\hline Bonuses should be a part of the company policy & 4.2846 & .71884 & 123 \\
\hline $\begin{array}{l}\text { Hotel recognizes the extra effort I put into my } \\
\text { job }\end{array}$ & 3.2195 & .77393 & 123 \\
\hline $\begin{array}{l}\text { Rewards should be given according to on } \\
\text { performance }\end{array}$ & 3.8293 & 68601 & 123 \\
\hline $\begin{array}{l}\text { Are you happy with the current remuneration } \\
\text { system of } \\
\text { your hotel }\end{array}$ & 2.3008 & 1.03966 & 123 \\
\hline \multicolumn{4}{|l|}{ Overall mean 2.94} \\
\hline Lowest mean 2.3 & & & \\
\hline Highest mean 4.28 & & & \\
\hline
\end{tabular}


The Level of performance appraisal practices of hotels in Delhi is presented in Table 2. The result shows the level of performance appraisal practices in 2 and 3 -star hotels of Delhi have a high $(X=4.28)$ level of performance appraisal practices. The lowest is $(X=2.3)$ and the average mean for the performance appraisal practices in hotels of Delhi is $(\mathrm{X}=2.9)$

This considers 'awareness of performance appraisal system in the organization' $(\mathrm{X}=2.63, \mathrm{SD}=0.82)$, 'Hotel has fair promotion opportunities for every employee' $(\mathrm{X}=2.83, \mathrm{SD}=1.019)$, 'Promotion is totally based on employee performance' $(X=2.93, S D=0.964)$, 'My job is helping me in my career' $(\mathrm{X}=2.81, \mathrm{SD}=0.935)$, 'My superior provides me equal opportunities' $(\mathrm{X}=2.56$, $\mathrm{SD}=1.095)$, 'Working with this hotel is enjoyable' $(\mathrm{X}=2.75, \mathrm{SD}=0.98)$, 'Good result of performance appraisal will lead to promotion' ( $\mathrm{X}=2.64, \mathrm{SD}=1.017)$, 'Do you love to accept challenges related to your job' $(X=2.86, S D=1.155)$, 'Are you aware about the goals of your hotel' $(X=3.27, S D=0.278)$, 'Do you have favorable work culture and environment' $(\mathrm{X}=2.81, \mathrm{SD}=1.189)$, 'Does your manager communicate the right information about your appraisal' $(\mathrm{X}=2.75, \mathrm{SD}=1.198)$ 'Does your superior delegate authority to employees' $(\mathrm{X}=2.74, \mathrm{SD}=1.135)$ 'Bonuses should be a part of company policy' $(\mathrm{X}=4.28$, $\mathrm{SD}=0.718)$, 'Hotel recognizes the extra effort I put into my job' $(\mathrm{X}=3.22$, $\mathrm{SD}=0.77$ ), 'Rewards should be given according to performance' ( $\mathrm{X}=3.83$, $\mathrm{SD}=0.77$ ), 'Are you happy with the current remuneration system of your hotel' $(\mathrm{X}=2.30, \mathrm{SD}=1.039)$.

The key findings indicated that satisfaction with performance appraisal process sanguinely influences employees' work performance and effective organizational commitment whereas unconstructively influences employees' turnover intention. In adding, the liaison between satisfaction with performance appraisal and work performance was fully mediated by intrinsic motivation whereas the relationship between performance appraisal satisfaction and affective organizational commitment and turnover intention were partially mediated by intrinsic motivation.

Hence, H1: There is a set of performance appraisal practices which are used in 2 stars and 3-star hotels in Delhi NCR, is accepted and the findings indicate that there are performance appraisal practices in the selected sample hotels. 
Table 3 Descriptive Statistics and Correlations

\begin{tabular}{llllllll}
\hline \multicolumn{1}{c}{} & Mean & SD & 1 & 2 & 3 & 4 & 5 \\
\hline $\begin{array}{l}\text { Type of } \\
\text { Hotel }\end{array}$ & 1.5203 & .50613 & 1.00 & & & & \\
$\begin{array}{l}\text { Promotion is } \\
\text { totally based }\end{array}$ & 2.93 & .96445 & $0.68^{*}$ & 1.00 & & & \\
$\begin{array}{l}\text { on employee } \\
\text { performance }\end{array}$ & & & & & & & \\
Category of & 2.5285 & .50123 & $0.43^{* *}$ & 0.99 & 1.00 & & \\
hotel & & & & & & & \\
$\begin{array}{l}\text { Age } \\
\text { Education }\end{array}$ & 2.0732 & .95102 & 0.95 & 0.02 & 0.02 & 1.00 & \\
\hline
\end{tabular}

Note: ${ }^{* * *}$ p, .001 (2-tailed); ${ }^{* *}$ p, .01 (2-tailed); *p, .05 (2-tailed)

In order to measure the affiliation between some of the demographic variables and dependence of promotion on employee performance practices (Promotion is totally based on employee performance), in other words, to be proficient to test hypothesis 2 bivariate analysis was done. The findings of this analysis specify that all means are a lot below level 3 in a 5-level Likert scale. Table 3 describes the descriptive statistics and correlation in demographic variables and performance appraisal practice (Promotion is totally based on employee performance). The result shows that there is a correlation between the performance appraisal practice "Promotion is totally based on employee performance" and demographic characteristics.

Hence, H2: There is a positive relationship between the promotion policies and demographic characteristics of hotels is accepted and it shows a positive correlation between employee performance and their demographic characteristics.

\section{G. Conclusion \& Suggestions}

The present study investigated several performance appraisal dimensions. The purpose of conducting this study was to study the impact of performance appraisal on employee 's motivation and work performance in the hotel industry. The questionnaire was developed for gathering the information and selected 123 hotel employees as the sample of research which covered executive and supervisory level employees. The research findings indicated that the use of performance appraisal practices is quite low. The findings suggested that the awareness about performance appraisal practices is low amongst the employees of the selected category of hotels. The performance appraisal policies should be more practical and employees should have a sense of fairness regarding the implementation of these performance appraisal practices. The study shows that 
personal biases in promotion policies and imparting monetary benefits have been perceived by the employees. This study also indicates that employees are aware of the benefits of good performance appraisal practices but feel their organization lacks in proper human resource management.

Considering the results and findings of the study the following recommendations can be drawn:

1. The performance appraisal practices have to be used more for employee development and satisfaction in 2 star and 3-star category hotels.

2. There is a need to understand the challenges and to adopt new trends in the hotel industry.

3. Human Resource manager's/ Department managers should use effective tools and techniques for performance appraisal.

4. The benefits of performance appraisal practices have to be utilized for practical purposes rather than them being used just to reflect it on paper.

5. It is suggested that performance appraisal information may be used for determining the training $\&$ development needs of employees.

\section{REFERENCES}

Adekunle, S., \& Wu, B. (2005). The Philosophy And Practice of Management By Objectives.

Armstrong, M., \& Baron, A. (2004). Managing Performance: Performance Management in action, CIPD.

Cunneen, P. (2006) How to improve performance management. People Management. Vol 12, No 1, 12 January. pp42-43.

Delery, J. E., \& Doty, D. H. (1996). Modes of theorizing in strategic human resource management: Tests of universalistic, contingency, and configurational performance predictions. Academy of Management Journal, 39(4), 802-835.

Fathin, Almirah., Lestari Ningrum., and Ahmad Junaedi Abas. 2018. The Influence of Recruitment Process on Performance and Job Satisfaction at The Dharmawangsa Jakarta. Tourism Research Journal. Vol. 2, No. 1: 76 $-91$.

Huang, C. D., \& Hu, Q. (2007). Achieving IT-business strategic alignment via enterprise-wide implementation of balanced scorecards. Information Systems Management, 24(2), 173-184. 
Kaplan, R. S., \& Norton, D. P. (1996). Using the balanced scorecard as a strategic management system.

Locke, E. A., \& Latham, G. P. (2004). What should we do about motivation theory? Six recommendations for the twenty-first century. Academy of management review, 29(3), 388-403.

Marion, G., (1998), Corporate Communications Managers in Large Firms: New Challenges, European Management Journal, 16, pp.660-671.

Nyembezi, V. (2009). Development of a performance management system for the SABC (Port Elizabeth). A published Masters degree in Business Administration thesis. Port Elizabeth: Nelson Mandela Metropolitan University Business School.

Schneier, C. E., Beatty, R. W. and Baird, L.S, (1987), Performance Appraisal Sourcebook. Human Resources Development Press, Amberst.

Teke, M. 2002. Retention Strategy. HR Future. March 2002, 10-12.

Welch, M., \& Jackson, P. R. (2007). Rethinking internal communication: a stakeholder approach. Corporate Communications: An International Journal, 12(2), 177-198. 